\title{
Developing Orphanage Adolescents Stress Scale
}

\author{
Amira Hassan Abd-AlFatah, Hamdy Nageeb El-Tallawy, Hekmat Ibrahim Abd El-Karim \\ \& Marzoka Abd-Al Aziz Gadallah.
}

Assistant Lecturer in Pediatric and Premature Nursing, Faculty of Nursing, Assiut University.

Professor of Psychiatric Medicine, Faculty of Medicine, Assiut University.

Assistant Professor of Pediatric Nursing , Faculty of Nursing, Assiut University.

Assistant Professor of Pediatric Nursing , Faculty of Nursing, Assiut University.

\begin{abstract}
Stress is a natural part of every adolescent's life. Adolescents in orphanage are more liable for stress than other adolescents. The aim of this study was to develop Orphanage Adolescents Stress Scale. Tool: The Orphanage Adolescents Stress Scale was developed by the researcher. Subjects and method: This questionnaire surveys were conducted with 74 adolescents to examine the psychometric properties. The final Orphanage Adolescents Stress Scale 58-items contain four domains: Emotional deprivation, Future planning, Relationships inside the organization, Relationships outside the organization and Stress symptoms. Result: Scale scores showed satisfactory internal consistency and two weeks test-retest reliability. Conclusion: OASS is an effective scale with acceptable psychometric properties and was especially adapted to measure stress in orphanage adolescents. Recommendations: For researchers who have a particular interest in stress among orphan adolescents, the OASS suggested to be effective tool.
\end{abstract}

\section{Key words: Adolescents, Stress, Scale \&Orphanage.}

\section{Introduction}

Adolescence is known as a period of stress and strain, Adolescent ' stress is usually related to everyday experiences, worries and challenges at school, home, in the community and within their peer group. The impact of unresolved stress can lead to feelings of anxiety, depression, irritability, poor concentration, aggression, physical illness, fatigue, sleep disturbance and poor coping skills such as tobacco, drug or alcohol use (Nangia \& Sareen ,2011).

Stress has long been a major research concept in health science since, it is linked to various health outcomes and illnesses, including cancer, diabetes, cardiovascular disease, asthma, and rheumatoid arthritis (Cohen et al., 2007) (Johnson et al., 2002). The ways in which the concept of stress has been assessed in research can be classified broadly into three perspectives: environmental which focusing on stressors or life events; The second is psychological while assessing subjective stress appraisal and affective reactions and biological that include, assessing the activation of the physiological systems involved in the stress response (Cohen \&Kessler, 1997) \& (Kopp et al., 2010).

Orphanages are long term residential centers that provide all basic developmental needs for children who have lost one or both biological parents. In reality, they also admit a variety of children at risk and children in need of special protection, but are often unable to provide specialized services (Orphanage adoption Encylopedia,2012) UNICEF and global partners define an orphan as a child under
18 years of age who has lost one or both parents to any cause of death. By this definition, there were nearly 140 million orphans globally in 2015. Mental health problems continued to increase within the orphanage. Greater numbers of young children with increasingly complicated and serious physical, mental health, and developmental problems are being placed in orphanage ( Ferrara et al.,2013).

Dawood, (1995) developed Psychological Stress Scale as a new instrument used to measure level of stress among adolescent students. There is no scales were developed to measure stress among orphan adolescents so the researcher develops Orphanage Adolescents Stress Scale as a new instrument that will be used by pediatric nurses to measure stress among this target of population who suffer from multiple psychological problems.

\section{Aim of the study}

The aim of this study was to develop Orphanage Adolescents Stress Scale.

\section{Subjects and Method \\ Research Design}

Descriptive research design was used in this study. Setting

The study was conducted at the three orphanages of Assiut city (Lelian Trasher, Dar- Elsafa and DarElhanan). These orphanages receive orphan children from one year to 18 years. 


\section{Subjects}

The study subjects included a convenience sampling of all the orphan adolescents in the three orphanages (74) either males or females and their ages ranged from 12- 18 years.

\section{Research questions}

Is Orphanage adolescents stress scale effective in measuring stress among orphanange adolescents?

Is Orphanage adolescents stress scale reliable?

\section{Tools of data collection:}

\section{Phases of developing OASS}

First Phase, the researcher reviewed literature about orphan adolescents to identify their problems. In the second phase the researcher identified the domains and constructed a group of statements below each domain and put infornt of each statement "suitable" or "unsuitable". Statements of the scale were initially created in Arabic. The third phase the researcher gave the scale to experts in the field of child psychology from Faculty of Education, Faculty of Medicine and Faculty of Nursing to evaluate the scale. Necessary modifications of the scale was made and finally the scale format was in the final shape. The Orphanage Adolescents stress scale (OASS) consists of 58 items, 54 positive items and 4 negative items distributed through four domains, The first domain is emotional deprivation (13 items), such as "No one takes care of me", the second is future planning (11items), such as "I feel hopelessness", the third domain include two parts, Part a- relations inside the organization (16items), as "There is disagreement between me and my friends inside the organization". Part b- relations outside the organization (7items), such as "I feel that others consider me little than them" and the fourth domain is stress symptoms (11items), such as "I suffer from sleep disorders".

\section{Method}

Official permission was obtained from the Ministry of Social Insurance to collect data from the three orphanages in Assiut city. A Pilot Study was carried out on $10 \%$ of the adolescents to test the clarity and applicability of the tool. Based on the results of the pilot study no modification in the scale was done (and they were included in the study). This study was conducted in March and April in 2016.

The researcher illustrated each item in OASS during the interview with orphan adolescents. A brief introduction was given by the researcher followed by the distribution of scale on them .Orphan adolescents took about 15 minutes to answer the scale.

\section{Content validity}

The scale was evaluated by nine experts, five experts in child psychology from the Faculty of Education in Assiut University, two experts in neurology and psychiatry department from the Faculty of Medicine in Assiut University and two experts in pediatric nursing from Faculty of Nursing in Assiut University to referee the scale. Content validity of the OASS was $95 \%$.

\section{Scale Reliability}

The internal consistency reliability was assessed by using Cronbach's alpha and average inter item correlation. Reliability of this scale was done by using (Test- Retest) and the time between first application and second application was two weeks. Reliability score for this sample was 0.94 by using Cronbach's Alpha test and reliability was calculated for each domain as following: for emotional deprivation domain was 0.78 , for future planning domain was 0.803 , for relation inside the organization was 0.74 , for relation outside the organization was 0.78 , for stress symptoms domain was 0.89 .

Scoring system of Orphanage adolescents stress scale

Each item in this scale was measured by three likert scale (don't agree $=0$, agree for some degree $=1$ and agree=2). The total score of this scale is divided into $<50 \%$ shows that the adolescent suffers from mild degree of stress and 50- $<75 \%$ shows that the adolescent suffers from moderate degree of stress and $\geq 75$ shows that the adolescent suffers from a highest degree of stress.

The final Phase the scale was translated into English and sent to be judged by experts to revise it after translation.

\section{Ethical Considerations}

Research proposal was approved from Ethical Committee in the Faculty of Nursing then from Ministry of social insurance to collect data from the three orphanages in Assiut city. The researcher explained the purpose and nature of the study for each adolescent. The child has the right to agree or disagree to participate in the study; a written consent to participate in the study was secured from every adolescent and informed that the obtained information will be confidential and will be used only for the purpose of the study. There was no risk for study subject during application of the research.

\section{Data Analysis}

Analysis were conducted using IBM SPSS 20.0. All statistical tests were two-sided and significance level was defined as $\mathrm{a}=0.05$. 


\section{Results}

Table (1): Percentages distribution of orphan adolescents related to personal data.

\begin{tabular}{|c|c|c|}
\hline \multirow{2}{*}{ Items } & \multicolumn{2}{|c|}{ Orphan adolescent } \\
\hline & $n=74$ & $\%$ \\
\hline \multicolumn{3}{|l|}{ Age } \\
\hline $12-<15$ years & 27 & 36.5 \\
\hline $15-\leq 18 y e a r s$ & 47 & 63.5 \\
\hline Mean \pm SD & \multicolumn{2}{|c|}{$15.2 \pm 1.79$} \\
\hline \multicolumn{3}{|l|}{ Sex } \\
\hline Male & 65 & 87.8 \\
\hline Female & 9 & 12.2 \\
\hline \multicolumn{3}{|l|}{ Organizations names } \\
\hline Dar El-Hanan & 15 & 20.3 \\
\hline Dar El-Safa & 9 & 12.2 \\
\hline LelianTrasher & 50 & 67.6 \\
\hline \multicolumn{3}{|l|}{ Education level } \\
\hline Preparatory & 28 & 37.8 \\
\hline Secondary & 46 & 62.2 \\
\hline
\end{tabular}

Table (2-A): Rotated Factor Loadings and Communalities $\left(h^{2}\right)$ for the OASS in the EFA.

\begin{tabular}{|c|c|c|c|c|c|c|}
\hline \multirow[b]{3}{*}{$\begin{array}{c}\text { Domains of OASS } \\
\text { And its items }\end{array}$} & \multicolumn{5}{|c|}{ EFA $(n=74)$} & \multirow[b]{3}{*}{ h2 } \\
\hline & \multicolumn{5}{|c|}{ Factor loadings } & \\
\hline & $\begin{array}{c}\text { Emotional } \\
\text { Deprivation } \\
\text { (1) }\end{array}$ & $\begin{array}{l}\text { Future } \\
\text { Planning } \\
(2)\end{array}$ & $\begin{array}{c}\text { Relation } \\
\text { inside the } \\
\text { Organization } \\
\text { (3) }\end{array}$ & $\begin{array}{c}\text { Relation } \\
\text { outside the } \\
\text { Organization } \\
(4)\end{array}$ & $\begin{array}{c}\text { Stress } \\
\text { Symptoms } \\
(5)\end{array}$ & \\
\hline \multicolumn{7}{|c|}{ First Domain: Emotional Deprivation } \\
\hline $\begin{array}{l}\text { No one takes care of } \\
\text { me }\end{array}$ & 0.13 & 0.13 & -0.11 & 0.50 & 0.10 & 0.30 \\
\hline I feel insecure & 0.02 & 0.24 & 0.19 & 0.52 & 0.15 & 0.29 \\
\hline $\begin{array}{l}\text { I lose warmness in } \\
\text { my life }\end{array}$ & 0.27 & 0.11 & -0.05 & 0.62 & 0.15 & 0.49 \\
\hline $\begin{array}{l}\text { 4-No one encourages } \\
\text { me }\end{array}$ & 0.33 & 0.11 & -0.14 & 0.54 & -0.03 & 0.43 \\
\hline $\begin{array}{l}\text { Nightmares attack } \\
\text { me }\end{array}$ & -0.10 & -0.04 & 0.03 & 0.59 & 0.16 & 0.28 \\
\hline $\begin{array}{lr}\begin{array}{l}\text { Sometimes, I feel } \\
\text { extremely } \\
\text { without } \\
\text { anger } \\
\text { cause }\end{array} & \\
\end{array}$ & 0.25 & 0.00 & 0.29 & 0.55 & -0.08 & 0.31 \\
\hline $\begin{array}{l}\text { I have no enthusiasm } \\
\text { for doing anything }\end{array}$ & 0.51 & 0.06 & 0.08 & 0.50 & 0.03 & 0.47 \\
\hline $\begin{array}{l}\text { 8-Sometimes I feel } \\
\text { stressed and nervous } \\
\text { without an obvious } \\
\text { cause }\end{array}$ & 0.21 & 0.15 & 0.31 & 0.56 & -0.01 & 0.35 \\
\hline $\begin{array}{l}\text { There is no joy in my } \\
\text { life }\end{array}$ & 0.12 & 0.27 & 0.03 & 0.57 & 0.22 & 0.33 \\
\hline $\begin{array}{l}\text { I feel exhausted in } \\
\text { doing my daily works }\end{array}$ & 0.59 & 0.05 & 0.26 & 0.13 & 0.14 & 0.25 \\
\hline
\end{tabular}




\begin{tabular}{|c|c|c|c|c|c|c|}
\hline \multirow[b]{3}{*}{$\begin{array}{c}\text { Domains of OASS } \\
\text { And its items }\end{array}$} & \multicolumn{5}{|c|}{ EFA $(n=74)$} & \multirow[b]{3}{*}{ h2 } \\
\hline & \multicolumn{5}{|c|}{ Factor loadings } & \\
\hline & $\begin{array}{l}\text { Emotional } \\
\text { Deprivation } \\
\text { (1) }\end{array}$ & $\begin{array}{l}\text { Future } \\
\text { Planning } \\
\quad(2)\end{array}$ & $\begin{array}{c}\text { Relation } \\
\text { inside the } \\
\text { Organization } \\
\text { (3) }\end{array}$ & $\begin{array}{c}\text { Relation } \\
\text { outside the } \\
\text { Organization } \\
\text { (4) }\end{array}$ & $\begin{array}{c}\text { Stress } \\
\text { Symptoms } \\
(5)\end{array}$ & \\
\hline $\begin{array}{l}11-\mathrm{I} \text { have a self } \\
\text { confidence }\end{array}$ & -0.27 & 0.53 & -0.04 & 0.09 & -0.09 & 0.21 \\
\hline $\begin{array}{lr}\text { 12-others } & \text { cannot } \\
\text { understand } & \text { my } \\
\text { feelings } & \end{array}$ & 0.58 & 0.10 & 0.04 & 0.28 & -0.18 & 0.35 \\
\hline $\begin{array}{l}\text { 13- I am easily } \\
\text { manageable by others }\end{array}$ & -0.07 & 0.14 & -0.13 & 0.56 & 0.35 & 0.29 \\
\hline
\end{tabular}

Table (2-B): Rotated Factor Loadings and Communalities $\left(h^{2}\right)$ for the OASS in the EFA.

\begin{tabular}{|c|c|c|c|c|c|c|}
\hline \multirow[b]{3}{*}{$\begin{array}{c}\text { Domains of OASS } \\
\text { And its items }\end{array}$} & \multicolumn{5}{|c|}{$\operatorname{EFA}(n=74)$} & \multirow[b]{3}{*}{ h2 } \\
\hline & \multicolumn{5}{|c|}{ Factor loadings } & \\
\hline & $\begin{array}{l}\text { Emotional } \\
\text { Deprivation } \\
\text { (1) }\end{array}$ & $\begin{array}{l}\text { Future } \\
\text { Planning } \\
\quad(2)\end{array}$ & $\begin{array}{c}\text { Relation } \\
\text { inside the } \\
\text { Organization } \\
(3)\end{array}$ & $\begin{array}{c}\text { Relation } \\
\text { outside the } \\
\text { Organization } \\
(4)\end{array}$ & $\begin{array}{c}\text { Stress } \\
\text { Symptoms } \\
(5)\end{array}$ & \\
\hline \multicolumn{7}{|c|}{ Second Domain: Future Planning } \\
\hline I feel useless & 0.54 & 0.22 & 0.02 & 0.17 & 0.14 & 0.31 \\
\hline $\begin{array}{l}\text { I am indecisive in } \\
\text { taking important } \\
\text { decisions in my life }\end{array}$ & 0.55 & -0.21 & 0.09 & 0.03 & 0.18 & 0.39 \\
\hline I feel hopelessness & 0.53 & 0.22 & 0.12 & $\mathbf{0 . 5 0}$ & 0.22 & 0.31 \\
\hline $\begin{array}{l}\text { 4-I am afraid of the } \\
\text { future }\end{array}$ & 0.55 & -0.02 & 0.19 & -0.02 & 0.07 & 0.25 \\
\hline $\begin{array}{l}\text { My goals are un } \\
\text { specified }\end{array}$ & 0.57 & 0.06 & -0.01 & -0.03 & 0.00 & 0.33 \\
\hline $\begin{array}{l}\text { It is difficult for me } \\
\text { to start doing any } \\
\text { thing }\end{array}$ & 0.58 & 0.22 & 0.07 & 0.03 & 0.30 & 0.29 \\
\hline $\begin{array}{l}\text { in the future, I am } \\
\text { afraid of thinking in } \\
\text { marriage }\end{array}$ & 0.62 & 0.09 & 0.13 & 0.11 & -0.04 & 0.10 \\
\hline $\begin{array}{l}\text { I feel that life is } \\
\text { worthless }\end{array}$ & 0.66 & 0.29 & 0.26 & 0.22 & 0.08 & 0.34 \\
\hline $\begin{array}{l}\text { I feel my future will } \\
\text { be dark }\end{array}$ & 0.75 & 0.25 & 0.21 & 0.25 & 0.09 & 0.38 \\
\hline $\begin{array}{l}\text { I do not have well } \\
\text { defined vision about } \\
\text { my future }\end{array}$ & 0.65 & 0.22 & 0.07 & 0.13 & 0.08 & 0.28 \\
\hline $\begin{array}{l}\text { It is difficult to get } \\
\text { job in the future }\end{array}$ & 0.53 & 0.06 & 0.10 & 0.11 & 0.02 & 0.31 \\
\hline
\end{tabular}


Table (2-C): Rotated Factor Loadings and Communalities $\left(h^{2}\right)$ for the OASS in the EFA.

\begin{tabular}{|c|c|c|c|c|c|c|}
\hline \multirow{3}{*}{$\begin{array}{l}\text { Domains of OASS } \\
\text { And its items }\end{array}$} & \multicolumn{5}{|c|}{$\operatorname{EFA}(n=74)$} & \multirow[b]{3}{*}{ h2 } \\
\hline & \multicolumn{5}{|c|}{ Factor loadings } & \\
\hline & $\begin{array}{l}\text { Emotional } \\
\text { Deprivation } \\
\text { (1) }\end{array}$ & $\begin{array}{l}\text { Future } \\
\text { Planning } \\
\text { (2) }\end{array}$ & $\begin{array}{c}\text { Relation } \\
\text { inside the } \\
\text { Organization } \\
(3)\end{array}$ & $\begin{array}{c}\text { Relation } \\
\text { outside the } \\
\text { Organization } \\
(4)\end{array}$ & $\begin{array}{c}\text { Stress } \\
\text { Symptoms } \\
(5)\end{array}$ & \\
\hline \multicolumn{7}{|c|}{ Third Domain: A-Relation inside the organization } \\
\hline $\begin{array}{l}\text { There is disagreement } \\
\text { between me and my } \\
\text { friends inside the } \\
\text { organization }\end{array}$ & 0.05 & 0.64 & 0.13 & 0.15 & 0.39 & 0.32 \\
\hline $\begin{array}{l}\text { I am in continuous } \\
\text { disagreement with } \\
\text { supervisors of the } \\
\text { organization }\end{array}$ & -0.13 & 0.04 & -0.08 & 0.06 & 0.67 & 0.48 \\
\hline $\begin{array}{l}\text { Organization members } \\
\text { do not understand me }\end{array}$ & 0.17 & 0.31 & 0.06 & -0.13 & 0.56 & 0.27 \\
\hline $\begin{array}{l}\text { There is no trust } \\
\text { between me and my } \\
\text { colleagues }\end{array}$ & 0.12 & 0.17 & -0.06 & 0.17 & 0.48 & 0.31 \\
\hline $\begin{array}{l}\text { Organization's } \\
\text { supervisors have } \\
\text { differential } \\
\text { management between } \\
\text { me and my colleagues }\end{array}$ & 0.18 & 0.21 & 0.03 & -0.08 & 0.55 & 0.38 \\
\hline $\begin{array}{l}\text { I have been exposed } \\
\text { to deception from a } \\
\text { dear friend (stealing- } \\
\text { disclosure of a secret) }\end{array}$ & 0.21 & 0.55 & 0.07 & 0.05 & 0.21 & 0.22 \\
\hline $\begin{array}{l}\text { I begin talking to my } \\
\text { colleagues }\end{array}$ & -0.17 & 0.53 & 0.13 & 0.17 & 0.00 & 0.26 \\
\hline $\begin{array}{l}\text { I wait my colleagues to } \\
\text { begin talking to me }\end{array}$ & -0.03 & 0.09 & 0.24 & 0.59 & 0.03 & 0.22 \\
\hline $\begin{array}{l}\text { My organization } \\
\text { colleagues are } \\
\text { scheming } \\
\text { machinations to me }\end{array}$ & 0.15 & 0.10 & 0.04 & 0.08 & 0.62 & 0.22 \\
\hline $\begin{array}{l}\text { My colleagues do not } \\
\text { understand my feelings }\end{array}$ & 0.15 & 0.55 & 0.16 & 0.09 & 0.15 & 0.38 \\
\hline $\begin{array}{l}\text { I have strong relations } \\
\text { with my organization } \\
\text { colleagues }\end{array}$ & -0.02 & 0.53 & -0.11 & -0.23 & -0.44 & 0.36 \\
\hline $\begin{array}{l}\text { organization } \\
\text { supervisors don not } \\
\text { encourage me }\end{array}$ & 0.24 & 0.56 & -0.22 & -0.17 & 0.08 & 0.35 \\
\hline $\begin{array}{l}\text { I have been socially } \\
\text { accepted in the } \\
\text { organization }\end{array}$ & 0.16 & 0.08 & 0.52 & 0.03 & -0.12 & 0.09 \\
\hline $\begin{array}{l}\text { Hate and antagonism } \\
\text { prevail between me } \\
\text { and my organization } \\
\text { colleagues }\end{array}$ & -0.06 & 0.21 & 0.23 & 0.06 & 0.59 & 0.25 \\
\hline
\end{tabular}




\begin{tabular}{|c|c|c|c|c|c|c|}
\hline \multirow{3}{*}{$\begin{array}{c}\text { Domains of OASS } \\
\text { And its items }\end{array}$} & \multicolumn{5}{|c|}{$\operatorname{EFA}(n=74)$} & \multirow[b]{3}{*}{ h2 } \\
\hline & \multicolumn{5}{|c|}{ Factor loadings } & \\
\hline & $\begin{array}{c}\text { Emotional } \\
\text { Deprivation } \\
\text { (1) }\end{array}$ & $\begin{array}{l}\text { Future } \\
\text { Planning } \\
\text { (2) }\end{array}$ & $\begin{array}{c}\text { Relation } \\
\text { inside the } \\
\text { Organization } \\
\text { (3) }\end{array}$ & $\begin{array}{c}\text { Relation } \\
\text { outside the } \\
\text { Organization } \\
(4)\end{array}$ & $\begin{array}{c}\text { Stress } \\
\text { Symptoms } \\
(5)\end{array}$ & \\
\hline $\begin{array}{l}\text { I have been exposed to } \\
\text { physical abuse from } \\
\text { organization } \\
\text { supervisors }\end{array}$ & 0.04 & -0.07 & 0.25 & 0.03 & 0.64 & 0.26 \\
\hline $\begin{array}{l}\text { I have been exposed } \\
\text { to corporal punishment }\end{array}$ & 0.02 & -0.07 & 0.20 & 0.05 & 0.51 & 0.31 \\
\hline
\end{tabular}

Table (2-D): Rotated Factor Loadings and Communalities $\left(h^{2}\right)$ for the OASS in the EFA.

\begin{tabular}{|c|c|c|c|c|c|c|}
\hline \multirow[b]{3}{*}{$\begin{array}{c}\text { Domains of OASS } \\
\text { And its items }\end{array}$} & \multicolumn{5}{|c|}{$\operatorname{EFA}(n=74)$} & \multirow[b]{3}{*}{ h2 } \\
\hline & \multicolumn{5}{|c|}{ Factor loadings } & \\
\hline & $\begin{array}{l}\text { Emotional } \\
\text { Deprivation } \\
\text { (1) }\end{array}$ & $\begin{array}{l}\text { Future } \\
\text { Planning } \\
\text { (2) }\end{array}$ & $\begin{array}{c}\text { Relation } \\
\text { inside the } \\
\text { Organization } \\
\text { (3) }\end{array}$ & $\begin{array}{c}\text { Relation } \\
\text { outside the } \\
\text { Organization } \\
(4)\end{array}$ & $\begin{array}{c}\text { Stress } \\
\text { Symptoms } \\
(5)\end{array}$ & \\
\hline \multicolumn{7}{|c|}{ Third Domain: B-Relation outside the organization } \\
\hline $\begin{array}{l}\text { I feel that others } \\
\text { consider me little } \\
\text { than them }\end{array}$ & 0.23 & 0.58 & 0.11 & 0.26 & 0.08 & 0.37 \\
\hline $\begin{array}{l}\text { I am not accepted by } \\
\text { the society }\end{array}$ & 0.12 & 0.52 & 0.10 & 0.26 & 0.33 & 0.37 \\
\hline $\begin{array}{l}\text { others misunderstand } \\
\text { me }\end{array}$ & 0.30 & 0.56 & 0.16 & -0.02 & 0.06 & 0.44 \\
\hline $\begin{array}{l}\text { I am unable to make } \\
\text { social relationships } \\
\text { with others }\end{array}$ & 0.04 & 0.58 & 0.17 & 0.28 & 0.24 & 0.40 \\
\hline $\begin{array}{l}\text { Thereis } \\
\text { discrimination in } \\
\text { dealing with me in } \\
\text { comparison to others }\end{array}$ & 0.20 & 0.61 & 0.06 & 0.31 & 0.07 & 0.51 \\
\hline $\begin{array}{l}\text { The society is } \\
\text { merciless with those } \\
\text { in my circumstances }\end{array}$ & 0.24 & 0.54 & 0.17 & 0.21 & -0.05 & 0.32 \\
\hline $\begin{array}{l}\text { People in society } \\
\text { refuse to deal with } \\
\text { those in my } \\
\text { circumstances }\end{array}$ & -0.04 & 0.50 & 0.15 & 0.17 & 0.16 & 0.24 \\
\hline
\end{tabular}


Table (2-E): Rotated Factor Loadings and Communalities $\left(h^{2}\right)$ for the OASS in the EFA.

\begin{tabular}{|c|c|c|c|c|c|c|}
\hline \multirow[b]{3}{*}{$\begin{array}{c}\text { Domains of OASS } \\
\text { And its items }\end{array}$} & \multicolumn{5}{|c|}{$\operatorname{EFA}(n=74)$} & \multirow[b]{3}{*}{ h2 } \\
\hline & \multicolumn{5}{|c|}{ Factor loadings } & \\
\hline & $\begin{array}{l}\text { Emotional } \\
\text { Deprivation } \\
\text { (1) }\end{array}$ & $\begin{array}{l}\text { Future } \\
\text { Planning } \\
\text { (2) }\end{array}$ & $\begin{array}{c}\text { Relation } \\
\text { inside the } \\
\text { Organization } \\
(3)\end{array}$ & $\begin{array}{c}\text { Relation } \\
\text { outside the } \\
\text { Organization } \\
(4)\end{array}$ & $\begin{array}{c}\text { Stress } \\
\text { Symptoms } \\
(5)\end{array}$ & \\
\hline \multicolumn{7}{|c|}{ Fourth Domain: Stress symptoms } \\
\hline $\begin{array}{l}\text { I suffer from sleep } \\
\text { disorders }\end{array}$ & 0.25 & -0.03 & 0.55 & 0.04 & 0.16 & 0.39 \\
\hline $\begin{array}{c}\text { I feel a desire to eat a } \\
\text { lot or little }\end{array}$ & 0.05 & 0.10 & 0.51 & 0.17 & 0.18 & 0.24 \\
\hline $\begin{array}{l}\text { I suffer from frequent } \\
\text { forgetfulness } r \text { and } \\
\text { difficulty to remember } \\
\text { things }\end{array}$ & 0.15 & 0.23 & 0.62 & -0.02 & 0.01 & 0.18 \\
\hline $\begin{array}{l}\text { I suffer from frequent } \\
\text { paroxysms of diarrhea, } \\
\text { constipation and } \\
\text { abdominal distension }\end{array}$ & 0.19 & 0.20 & 0.56 & -0.10 & 0.19 & 0.26 \\
\hline $\begin{array}{l}\text { I have pain in different } \\
\text { body parts and head }\end{array}$ & 0.05 & 0.19 & 0.67 & -0.21 & -0.02 & 0.53 \\
\hline $\begin{array}{l}\text { 6-I prefer isolation and } \\
\text { loneliness }\end{array}$ & 0.14 & 0.30 & 0.55 & -0.17 & 0.02 & 0.44 \\
\hline $\begin{array}{lr}\text { I suffer from some } \\
\text { neurotic traits such as } \\
\text { nail biting, urinary } \\
\text { incontinence and } \\
\text { pulling and removing } \\
\text { hair without medical } \\
\text { or pharmacological } \\
\text { cause }\end{array}$ & 0.31 & 0.23 & 0.53 & 0.21 & -0.09 & 0.31 \\
\hline I have tremors & 0.23 & 0.18 & 0.50 & 0.23 & 0.01 & 0.39 \\
\hline $\begin{array}{l}\text { I suffer from difficult } \\
\text { breathing }\end{array}$ & 0.15 & -0.19 & 0.53 & 0.23 & 0.13 & 0.32 \\
\hline $\begin{array}{l}\text { I am unable to control } \\
\text { my behavior }\end{array}$ & -0.07 & 0.05 & 0.49 & 0.24 & 0.00 & 0.30 \\
\hline $\begin{array}{lrr}\text { I suffer } & \text { from } \\
\text { disturbance in } & \text { my } \\
\text { practical } & & \text { daily } \\
\text { functions } & & \\
\end{array}$ & 0.18 & 0.11 & 0.56 & 0.09 & 0.10 & 0.37 \\
\hline
\end{tabular}

Note: OASS = Orphanage adolescent stress scale; $E F A=$ exploratory factor analysis; $h^{2}=$ Communalities. Factor loadings with values of 0.5 or greater in the EFA are shown in bold.Factorl=emotional deprivation domain, Factor2=future planning domain, Factor3=relation inside the organization, Factor4=relation outside the organization and factor $5=$ stress symptoms domain.

Table (1): Shows frequency and percentages distribution of orphan adolescents related to personal data. It was noticed that more than $60 \%$ of adolescents their ages ranged from $15-\leq 18$ years old. Regarding sex the majority of orphan adolescents were males. More than $60 \%$ of orphan were in preparatory schools and came from Lelian Trasher.
Table (2-A): Indicates rotated factor loading and communalities for OASS. It was noticed that items (1-9) and item (13) have a high factor loading on domain of relation outside the organization while items $(7,10,12)$ have a high factor loading on emotional deprivation. 
Table (2-B): Shows rotated factor loading and communalities for OASS. It was noticed that items (1-11) have a high factor loading on emotional deprivation domain.

Table (2-C): Illustrates rotated factor loading and communalities for OASS. It was noticed that items (2-5and14-16) have a high factor loading on domain of relation outside the organization while items $(1,6$, $7,10,11,12$ ) have a high factor loading on future planning domain .

Table (2-D): Shows rotated factor loading and communalities for OASS. It was noticed that items (1-7) have a high factor loading on future planning domain.

Table (2-E): Illustrates rotated factor loading and communalities for OASS. It was noticed that items (1-11) have a high factor loading on domain of relation inside the organization.

Exploratory Factor Analysis (EFA)

The factor structure of the preliminary 58-item of OASS was identified using EFA with principal axis factoring as the extraction method. The Promax method was used for rotation because the factors were thought to be correlated. The Kaiser-MeyerOlkin's measure (KMO) of sampling adequacy (acceptable level >0.50; Kaiser, 1970) and Bartlett's test of sphericity (Bartlett, 1950) were calculated to verify the appropriateness of an EFA. The number of factors was determined using parallel analysis (PA) performed with SPSS syntax developed by (O'Connor ,2000). Only items with a strong loading ( 0.50 or higher) on one factor were retained to form latent variables (Costello \& Osborne, 2005).

The EFA with data from the 58-item of OASS indicated that the sample and correlation matrix were appropriate for factor analysis (KMO Index $=0.75$ and Bartlett's test of sphericity was significant $\left[\mathrm{c}^{2}=\right.$ $3,912.50, p<0.001]$ ). Five factors were extracted based on PA analysis that cumulatively accounted for $64.3 \%$ of the total variance (Table 3 ).

On the basis of the data from the first survey $(N=$ 74), the Cronbach's alpha for the total 58-items of OASS was (0.94) indicating good internal consistency. The coefficient alpha for each factor ranged from ( 0.74 to 0.89 ) and most were above the criteria for an acceptable level of reliability. The average inter item correlations for the five factors were $(0.77,0.80,0.74,0.78$, and 0.89$)$ suggesting moderate to good reliability of 2 weeks.

\section{Discussion}

This research addresses psychometric properties of a new measure of stress in orphan adolescents .Development of a new instrument was driven by the need to measure stress in adolescents at orphanage. This Target of population suffers from stress as a result of many circumstances which threat their psychological balance and stability.

Scores from this scale exhibit satisfactory psychometric properties in terms of internal, testretest reliability. Application of a relatively high criterion to retain items in the final scale (Costello \& Osborne, 2005) resulted in 0 items of the initial items being dropped because high loadings on all factors. The application of this instrument is for community-based survey of orphan adolescents to examine psychological health associations of orphan stress. The average inter item correlations for all factors are well above the criterion $(\geq .30)$ for an acceptable internal consistency (Robinson et al., 1991) In addition, the number of items in each factor meets the minimum number of three items for best practice in factor analysis (Costello \& Osborne, 2005) The Cronbach's alphas for total scale and its domains were high value $(\alpha=0.94)$.

All domains were highly correlated with total scale, future planning domain was the most correlated domain with the total scale $(r=0.80)$ this indicated that orphan adolescents were worried about their future as a result of their circumstances. Followed by domain of relation outside the organization $(\mathrm{r}=0.78)$ this showed that society view for orphan children threat their psychological wellbeing and considered one of the major causes of their stress . Followed by domain of emotional deprivation domain $(\mathrm{r}=0.77)$ that illustrated absent or loss of parents in orphan adolescent represented the highly effective cause of their stress than other adolescents. Also, the most reliable domain was stress symptoms $(\alpha=0.88)$ which showed that the majority of orphan adolescents suffer from stress.

\section{Conclusion}

This scale demonstrates satisfactory psychometric properties and is suitable to be used to measure stress among orphan adolescents.

\section{Recommendations}

Based on the results of the present study, the following can be recommended

The OASS was only tested with orphan adolescents in Egypt and cross-cultural suitability is needed to be established to examine the difference between orphan adolescents in Egypt and in different countries all over the world to discuss the difference between orphan adolescents and their relationships with stress and other outcomes.

\section{References}

1. Bartlett M., (1950): Tests of significance in factor analysis. British Journal of Psychology $3,77-85$. 
2. Cohen S., Janicki-Deverts D., \& Miller G., (2007): Psychological stress and disease. Journal of the American Medical Association, 298, 16841687.

3. Cohen S., \& Kessler R., (1997): Measuring stress: A guide for health and socialscientists. Psychological Perspectives of stress. Ch (3), Oxford University Press.

4. Costello A., \& Osborne J., (2005): Best practices in exploratory factor analysis: Four recommendations for getting the most from your analysis. Practical Assessment Research \& Evaluation, Vol 10, Number (7). Retrieved from http://pareonline.net/getvn.asp.

5. Dawood N., (1995): Stressors encountered by junior high school students and their relation to grade point average, sex and grade. Jordan dean ship of academic research, Vol 22, Pp3671-3706.

6. Ferrara P., Romani L., \& Alvaro F.,(2013): the physical and mental health of children in foster care. iranian journal of public health .Vol 42,N(4) ,368-373.

7. Johnson S., Perry N., \& Rozensky R., (2002): Handbook of clinical health psychology: Medical disorder and behavioral applications ,Vol (1), American Psychological Association.

8. Kaiser H., (1970): A second generation little jiffy Psychometrika, Vol (35), 411-416.

9. Kopp M., Thega B., Balog P., Stauder A., Salaveez G., \& Rózsa S., (2010): Measures of stress in epidemiological research. Journal of Psychosomatic Research, Vol 69, 211-225.

10. Nangia A., \& Sareen S., (2011): Effectiveness of Training Program in Relaxation Techniques in reducing Academic and Social Stress among Adolescents, International Referred Research Journal, VOL-III ,ISSUE 25 , 3-4.

11. O'Connor B.,(2000): SPSS and SAS programs for determining the number of components using parallel analysis and Velicer's MAP test. Behavior Research Methods, Instruments, \& Computers, 32, 396-402.

12. Orphanage Adoption Enclopedia, (2012): https://en.m.wikipedia.org.

13. Robinson J., Shaver P., \&Wrightsman L., (1991): Criteria for scale selection and evaluation in measure of personality and social psychological attitudes. San Diego: California Academic Press. 